\title{
Characterization of a chromosomal mutant that blocks hemolysin excretion in Escherichia coli
}

\author{
F. Muñoa, J. Hacker and A. Juárez \\ Departamento de Microbiologia, Facultad de Biologia, Universidad de Barcelona, Avda. Diagonal, 645, 08028 Barcelona, Spain, \\ and Institut für Genetik und Mikrobiologie, Universität Wurzburg, Wurzburg, F.R.G.
}

Received 3 May 1988

Revision received 25 July 1988

Accepted 26 July 1988

Key words: Hemolysin excretion; Escherichia coli; Mutant

\section{SUMMARY}

We analyzed an Escherichia coli strain which harbours a chromosomal mutation that blocks the hemolysin excretion. Compartmentation studies showed that hemolysin accumulates in the cytoplasm and not in the periplasm. The mutation did not affect the SDS-PAGE protein pattern of the outer membrane, although some alterations were apparent in the periplasmic protein pattern. The mutant strain, E. coli Hsb-1 also failed to export a cloned fimbrial adhesin. The mutation maps in the $\min .3 .5$ of the $E$. coli genetic map.

\section{INTRODUCTION}

In the last few years, the Escherichia coli alpha-hemolysin displayed by some uropathogenic strains $[1-3]$, has been investigated mainly because of its role as a virulence factor. In addition,

Correspondence to: J. Hacker, Institut für Genetik und Mikrobiologie, Universităt Wurzburg, Röntgenring 11, 8700 Wurzburg, F.R.G. this toxin seems to be one of the very few proteins which are truly excreted to the external medium by $E$. coli cells [4]. Attention has therefore been focused on the mechanism controlling hemolysin excretion. This process shows some unique features: it has been reported that the cleavage of a $\mathrm{N}$-terminal signal peptide is not required [5], and recent results have also shown that a $\mathrm{C}$-terminal sequence of hemolysin is essential for the correct translocation of the toxin across the cell envelopes $[6,7]$. Nevertheless, the molecular mechanism of hemolysin excretion remains to be elucidated. The genetic determinant that allows $E$. coli to synthesize and export hemolysin may be either of chromosomal or plasmid origin. Irrespective of this, it includes two genes, $h l y B$ and $h l y D$, which are specifically required for the correct export of the active toxin to the external medium $[1,8]$. To date, the role of their gene products is poorly understood. Besides both the HlyB and HlyD proteins, it has been shown that other chromosomally coded functions also play a role in hemolysin export. We have already reported the isolation of a chromosomal mutation that blocked hemolysin secretion in $E$. coli. This mutation appeared to be specific for hemolysin export and did 
not affect the secretion to the periplasm of the $\beta$-lactamase, or the release of colicins to the external medium [9]. Here we further characterize such a mutant, and test the effect of the mutation on the export of a fimbrial agglutinin which is considered a protein translocated by $E$. coli to the external surface.

\section{MATERIALS AND METHODS}

\subsection{Bacterial strains, plasmiids and media}

The bacterial strains and plasmids used are listed in Table 1. LB medium [10] was routinely used for the maintenance and growth of the strains used. When required, ampicillin, chloramphenicol and tetracycline were prepared and used for supplementing the culture media at the concentrations indicated by Maniatis et al. [11].

\subsection{Genetic techniques}

Plasmid transformation and DNA isolation were performed as previously described [12]. Generalized transduction with $\mathrm{P} 1 \mathrm{~cm}$ clr100 phage was done as described by Miller [10]. For mapping experiments, an $\mathrm{Hfr}$ collection containing insertions of $\mathrm{Tn} 10$ around the $E$. coli chromosome was used [13] (Table 2). Fine mapping was performed by transducing $\operatorname{Tn} 10$ insertions near the region where the mutations were localized.
Table 2

Hfr-Tn 10 mapping strains (B. Bachmann)

\begin{tabular}{lll}
\hline Strain & $\begin{array}{l}\text { Hfr point } \\
\text { of origin }\end{array}$ & $\begin{array}{l}\text { Position of } \\
\text { the Tn } 10 \\
\text { insertion }\end{array}$ \\
\hline BW7261 & PO21 & leu63 \\
BW7623 & PO43 & purE \\
BW7622 & PO44 & trpBI14 \\
BW6160 & PO118 & zdh-57 \\
BW6163 & PO45 & zed-977 \\
BW6660 & PO66 & srlc-300 \\
BW6169 & PO13 & argA \\
BW6166 & PO18 & zhf-721 \\
BW6159 & PO68 & ilv-691 \\
BW6175 & PO131 & argE \\
BW6156 & PO3 & zje \\
BW6164 & PO48 & thr-43 \\
\hline
\end{tabular}

\subsection{Hemolysin assay}

The hemolytic activity was measured as follows. Bovine erythrocytes $(6 \mathrm{ml})$ were washed several times with $0.9 \% \mathrm{NaCl}$ and resuspended in $130 \mathrm{ml}$ of the same solution, to which $20 \mathrm{ml}$ of 0.2 $\mathrm{M} \mathrm{CaCl}_{2}$ were added. $600 \mu \mathrm{l}$ of this solution were mixed with $10-100 \mu 1$ of the corresponding sample to be assayed, and incubated at $37^{\circ} \mathrm{C}$. At different times, the samples were centrifuged (Eppendorf centrifuge) for $30 \mathrm{~s}$ and the release of hemoglobin was monitored as the increase in OD at $543 \mathrm{~nm}$. In order to compare the hemolytic activity in the supernatants of different cultures,

Table 1

Bacterial strains and plasmids

\begin{tabular}{|c|c|c|}
\hline Strain or plasmid & Relevant phenotype & Source or reference \\
\hline SK & $\mathrm{F}^{-}, \mathrm{r}_{\mathrm{k}}^{-} \mathrm{m}_{\mathrm{k}}^{-}, r p s L_{\mathrm{n}}, \mathrm{hr}$, thi, leu, lac $\mathrm{Z}$ & [12] \\
\hline HB101 & $\begin{array}{l}\mathrm{F}^{-}, \text {hsd } S 20\left(\mathrm{r}_{\overline{\mathrm{B}}}^{-} \mathrm{m}_{\mathrm{B}}^{-}\right), \sup E 44, \text { ara-14, galK-2, lacYl, proA2, } \\
\quad \text { rpsL20, xyl-5, mil-l, } \lambda^{-}, \operatorname{recA} 13\end{array}$ & [16] \\
\hline Hsb-1 & $5 \mathrm{~K}$ hsb.l::Mud 1 & [9] \\
\hline 536 & 06:K15:H31 & [16] \\
\hline NK5525 & $\mathrm{F}^{-}$, pro-81::Tn $10, \lambda^{-}$ & B. Bachmann \\
\hline JP3123 & $\mathrm{F}^{-}, \operatorname{lac} Y$, aroL::Tn 10, purE, tyrR, rpsL, $x y l, m l l$ & B. Bachmann \\
\hline NK5148 & $\mathrm{F}^{-}$, thr-34::Tn $10, \lambda^{-}$ & B. Bachmann \\
\hline NK6034 & Hfr (PO1), car-96::Tn 10, relA, $\Delta(g p t-l a c) 5$, spoT, thi, $\lambda^{-}$ & B. Bachmann \\
\hline SJ2 & Hfr (PO1), panB, zad-220::Tn 10, relA, spoT, thi, $\lambda^{-}$ & B. Bachmann \\
\hline$X 2844$ & $\mathrm{~F}^{-}, t s x-462:: \operatorname{Tn} 10, \lambda^{-}$ & \\
\hline pANN202-312 & $h l y C^{+}, h l y A^{+}, h l y B^{+}, h l y D^{+}, \mathrm{Cm}^{r}$ & [12] \\
\hline pANN202-312R & $h l y R^{+}, h l y C^{+}, h l y A^{+}, h l y B^{+}, h l y D^{+}, \mathrm{Cm}^{\mathrm{r}}$ & [7] \\
\hline pANN801-1 & $m r h^{+}, \mathrm{Tc}^{r}$ & [16] \\
\hline
\end{tabular}


the following units were used: 1 hemolytic unit = $\mathrm{OD}_{543} / \mathrm{OD}_{600} \times \min \times \mathrm{ml}$. For the periplasmic and cytoplasmic fractions, the hemolytic activity was calculated as specific activity (units/mg protein).

\subsection{Cell fractionation}

Cell fractionation was performed as described previously [14]. Proteins were separated on 10-13\% polyacrylamide gels [15] in a minigel apparatus (Bio-Rad Laboratories, Richmond, CA, U.S.A.).

\subsection{Agglutination}

Cells were grown in $\mathrm{LB}$ until an $\mathrm{OD}_{600}$ of 0.8 was reached. Hemagglutination was tested in microtiter plates using bovine erythrocytes as previously described [16].

\section{RESULTS}

4.1. Compartmentation of hemolysin in strain Hsb-1

To determine at which stage of the secretion process the mutant Hsb-1 is blocked, we studied the compartmentation of hemolysin in both this mutant and the parental $5 \mathrm{~K}$ strain. As hemolytic determinants we used either the plasmid pANN202-312, which was initially used for the isolation of the Hsb mutant [9], or its derivative pANN202-312R. When strain $5 \mathrm{~K}$ harbours the latter plasmid, the hemolytic activity is significantly increased in all cellular compartments, especially in the external medium (Table 3). When transformed with pANN202-312, strain Hsb-1 failed to excrete hemolysin, and hemolytic activity was present only in the cytoplasmic compartment

Table 3

Hemolysin production of strains $5 \mathrm{~K}$ and Hsb-1

\begin{tabular}{lccl}
\hline Strain & \multicolumn{3}{l}{ Hemolytic activity } \\
\cline { 2 - 4 } & $\begin{array}{l}\text { Exter- } \\
\text { nal }^{\mathrm{a}}\end{array}$ & $\begin{array}{l}\text { Periplas- } \\
\text { mic }^{\text {b }}\end{array}$ & $\begin{array}{l}\text { Cytoplas- } \\
\text { mic }^{\text {b }}\end{array}$ \\
\hline 5K(pANN202-312) & 0.005 & 0.36 & 0.25 \\
Hsb-l(pANN202-312) & $<0.001$ & $<0.001$ & 0.17 \\
5K(pANN202-312R) & 5.05 & 0.93 & 0.91 \\
Hsb-l(pANN202-312R) & 0.21 & 0.04 & 0.38 \\
\hline
\end{tabular}

a Values are given as units.

b Values are given as specific activity.

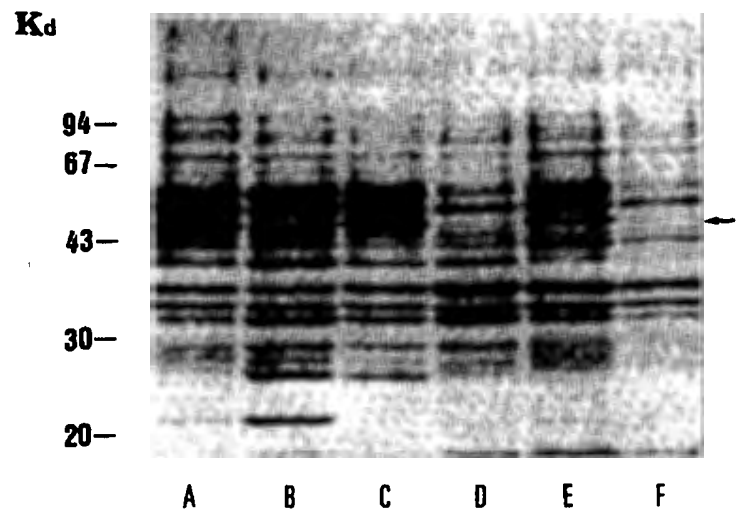

Fig. 1. SDS-PAGE periplasmic protein patterns from strains 5K and Hsb-1. A: 5K; B: 5K(pANN202-312); C: 5K(pANN202-312R); D: Hsb-1(pANN202-312); E: Hsb-1; F: Hsb-1(pANN202-312R).

(Table 3). In contrast, Hsb-1 clones harbouring pANN202-312R showed external as well as periplasmic hemolytic activity. Nevertheless, the activity values obtained for both fractions were no more than 5-10\% of those obtained for strain $5 \mathrm{~K}$ (pANN202-312R) (Table 3).

\subsection{Analysis of cell envelopes from strain $H s b-1$}

To obtain information about the effect of the $h s b$ mutation on the cell envelopes of strain Hsb-1, the protein composition of the outer membrane and periplasmic fractions was analyzed by SDSPAGE. The outer membrane protein pattern was found to be identical to that of the parental strain $5 \mathrm{~K}$ (data not shown). In contrast, different alterations were observed when the electrophoretic profiles of the periplasmic content were compared (Fig. 1). Some of them affected the relative ratios of different periplasmic proteins. Additionally, a major alteration was the absence of one $50 \mathrm{kDa}$ protein in strain Hsb-1. Interestingly, this protein was found to be absent only when strain Hsb-1 harboured either pANN202-312 or its derivative pANN202-312R (Fig. 1), and appeared in the periplasmic content of the plasmid free mutant strain.

\subsection{Expression of a fimbrial adhesin in strain $H s b-1$}

Previous results have shown that the hsb mutation did not affect either the secretion of the 
Table 4

Agglutination of $E$. coli Hsb-1 carrying plasmid pANN801-1

\begin{tabular}{llc}
\hline Strain & Plasmid & $\begin{array}{l}\text { Agglutination } \\
\text { title }\end{array}$ \\
\hline HB101 & pANN801-1 $^{\text {a }}$ & $1: 16$ \\
5K & pANN801-1 $^{\text {a }}$ & $1: 16$ \\
Hsb-1 & pANN801-1 $^{\text {a }}$ & $<1: 1$ \\
HB101 & pANN801-1 $^{\text {b }}$ & $1: 16$ \\
HB101 & None & $<1: 1$ \\
536 & None & $1: 2 / 0$ \\
\hline
\end{tabular}

Plasmid DNA obtained from strain HB101.

b Plasmid DNA reisolated from strain Hsb-1.

$\beta$-lactamase to the periplasm, or the release of colicins to the external medium [9]. Secretion of $\beta$-lactamase represents a translocation through the inner membrane, and the release of colicins seems to be caused by a specific mechanism, different from other secretion models and to hemolysin secretion itself $[17,18]$. In addition to this toxin, the fimbrial subunits and adhesins are also considered proteins which $E$. coli translocates to the external surface. Although no connection has been established until now between the two export mechanisms, we were interested to see if the hsb mutation could affect the adhesin transport. Strain Hsb-1 was transformed with the recombinant plasmid pANN801-1 $\left(\mathrm{Mrh}^{+} \mathrm{Fim}^{-}\right)$, which codes for the agglutinin determinant of $E$. coli 536, and the agglutinating activity of the tetracycline resistant transformants was tested. It was not possible to detect any agglutination for strain Hsb-1 (Table 4). The inability to agglutinate was not due

Table 5

Frequency of coinheritance of tetracycline resistance and extracellular hemolysin production in the matings of the $\mathrm{Hfr}-\mathrm{Tn} 10$ strains with Hsb-1 mutant

\begin{tabular}{lcl}
\hline Donor strain & $\begin{array}{l}\text { Tn10 map } \\
\text { position } \\
(\mathrm{min})\end{array}$ & $\begin{array}{l}\text { Frequency of } \\
\text { coinheritance } \\
\mathrm{Tc}^{\mathrm{r}} \mathrm{Hly}^{+}\end{array}$ \\
\hline BW6159 & 85 & 0.06 \\
BW6175 & 90 & 0.31 \\
BW6156 & 94 & 0.50 \\
BW6164 & 100 & 0.60 \\
BW7261 & 2 & 0.75 \\
BW7623 & 12 & 0.33 \\
\hline
\end{tabular}

Table 6

Cotransduction frequency between tetracycline resistance and extracellular hemolysis production

\begin{tabular}{lll}
\hline $\begin{array}{l}\text { P1 lysate obtained } \\
\text { from strain }\end{array}$ & $\begin{array}{l}\text { Tnl0 map } \\
\text { position (min) }\end{array}$ & $\begin{array}{l}\text { Frequency } \\
\text { of } \mathrm{Tc}^{r} \mathrm{Hly}^{+} \\
\text {transductants }\end{array}$ \\
\hline NK5148 & 0 & 0 \\
NK6034 & 1 & 0 \\
SJ2 & 3.5 & 0.91 \\
NK5525 & 6 & 0 \\
JP3123 & 9 & 0 \\
2844 & 9 & 0 \\
\hline
\end{tabular}

to changes in the recombinant plasmid pANN8011 because, after reisolation of this plasmid from strain Hsb-1, it retained the coding capacity for hemagglutination when retransformed in $E$. coli HB101 (Table 4).

\subsection{Mapping of the hsb mutation}

The location of the mutation in the $E$. coli chromosome was initially determined by using a Hfr::Tn 10 kit [13]. As the mutant was obtained by $\mathrm{Mu} d 1$ insertion, both $\mathrm{Hfr}$ matings and $\mathrm{Pl}$ transductions are easier to carry out with the Tn 10 transposon than with the much larger Mud1 genome. After crossing the different Hfr strains with strain Hsb-1 (pANN202-312), $\mathrm{Tc}^{r} \mathrm{Sm}^{r}$ clones were selected and tested for external hemolysin production. Hemolytic transconjugants could only be isolated using as donors $\mathrm{Hfr}$ strains which contained $\operatorname{Tn} 10$ inserted between mins. 85 and 12 of the $E$. coli genetic map, showing the highest frequency strains with $\mathrm{Tn} 10$ inserts between mins. 0 and 12 (Table 5). For fine mapping, $\mathrm{Tn} 10$ inserts covering this latter region were P1-transduced to strain Hsb-1, selecting for $\mathrm{Tc}^{r}$ transductants with hemolysis halos. Such a phenotype could be only obtained with P1 lysates grown on strain E. coli SJ2 (zad-220::Tn 10). The $\mathrm{Tc}^{r}$ phenotype in this strain is $96-98 \%$ cotransducible with pan $D$. The cotransduction frequency that we obtained for $\mathrm{Tc}^{r}$ and $\mathrm{Hly}_{\text {ext }}^{+}$was $91 \%$ (Table 6). Thus, we located the Mudl insert to about min. 3.5 of the E. coli genetic map, close to panD. 


\section{DISCUSSION}

The results presented above suggest that the stage at which hemolysin export is blocked in strain Hsb-1 is the translocation of the toxin through the inner membrane. We failed to detect hemolytic activity in the periplasmic compartment of strain Hsb-1, harbouring the multicopy hemolytic plasmid pANN202-312. Although this strain shows external as well as periplasmic hemolytic activity when it carries pANN202-312R, the activity values are much lower than those obtained for the parental strain. These results show that the $h s b$ mutation does not completely block hemolysin excretion. The increase in cytoplasmic hemolysin concentration caused by pANN202-312R allows a small percentage of hemolysin to be exported to the external medium, and Hsb clones harbouring this plasmid show small hemolysis halos on blood agar plates. In fact, we have been unable to isolate non-hemolytic mutants of 5K (pANN202-312R) (A. Juárez, unpublished data).

Supporting the results indicating that hemolysin accumulates in the cytoplasm of strain Hsb-1 and not in the periplasm, we show that when strain Hsb-1 harboured either pANN202-312 or pANN202-312R, SDS-PAGE analysis of the periplasmic proteins failed to show the $110 \mathrm{kDa}$ polypeptide which corresponds to the hemolysin. It has been shown that HlyB and HlyD proteins appear to be associated primarily with the cytoplasmic membrane [1]. Based on these results, it has been proposed that both HlyB and HlyD may form a transenvelope channel, thus allowing the exit of hemolysin [19]. Assuming this hypothesis, the $h s b$ gene(s) product(s) may be essential either for the correct assembly of the channel structure in the inner membrane, or for the interaction between hemolysin and HlyB and HlyD proteins. The fact that, when harbouring either pANN202312 or pANN202-312R, strain Hsb-1 lacks at least one major periplasmic protein, suggests that a defective translocation of hemolysin through the inner membrane interferes with the secretion of other periplasmic components.

A remarkable finding is that strain Hsb-1 also fails to agglutinate when harbouring a recombinant plasmid, which contains the agglutinin de- terminant. The results we present here suggest that both hemolysins and agglutinins may share some common cellular secretion factors, one of them being defective in strain $\mathrm{Hsb}-1$. The map location of the hsb locus does not correlate it to other previously known genes affecting protein export in $E$. coli. Cloning of the $h s b$ sequences and identification of the gene products coded may help to better understand the mechanism by which $E$. coli hemolysin is excreted to the external medium.

\section{ACKNOWLEDGEMENTS}

This work was supported in part with a grant from the CICYT (PB 86-0034) (to A. Juárez). The authors thank B. Bachmann for the $E$. coli strains harbouring $\operatorname{Tn} 10$ inserts around the genetic map.

\section{REFERENCES}

[1] Mackman, N., Nicaud, J.M., Gray, L. and Holland, I.B (1985) Mol. Gen. Genet. 201, 529-536.

[2] Müller, D., Hughes, C. and Goebel, W. (1983) J. Bacteriol. $153,846-851$.

[3] O'Hanley, P., Low, D. Romero, I., Lark, D. Vosti, K. Falkow, S. and Schoolnik, G. (1985) N. Engl. J. Med. 313, 414-420.

[4] Schmitz, G. and Braun, W. (1975) J. Bacteriol. 161, 1002-1009.

[5] Felmlee, T., Pellet, S. Lee, E.Y. and Welch, R.A. (1985) J. Bacteriol. 163, 88-93.

[6] Nicaud, J.M., Mackman, N. Gray, L. and Holland, I.B. (1986) FEBS Lett. 204, 331-335.

(7) Ludwig, A., Vogel, M. and Goebel, W. (1987) Mol. Gen. Genet. 206, 238-245.

[8] Wagner, W., Vogel, M. and Goebel, W. (1983) J. Bacteriol. $154,200-210$.

[9] Juárez, A. and Goebel, W. (1984) J. Bacteriol. 159 , 1083-1085.

[10] Miller, J.H. (1972) Experiments in Molecular Genetics Cold Spring Harbor Laboratory, Cold Spring Harbor, N.Y.

[11] Maniatis, T., Fritsch, E.F. and Sambrook, J. (1982) Molecular Cloning. Cold Spring Harbor Laboratory, Cold Spring Harbor, N.Y.

[12] Juárez, A., Hartlein, M. and Goebel, W. (1984)'J. Bacteriol. $160,161-168$

[13] Wanner, B.L. (1986) J. Mol. Biol. 191, 39-58. 
[14] Nieto, J.M., Tomás, J. and Juárez, A. (1987) FEMS Microbiol. Lett. 48, 413-417.

[15] Laemmli, V.K. (1970) Nature (London) 227, 680-685.

[16] Hacker, J., Schmidt, G., Hughes, C., Knapp, S., Marget, M. and Goebel, W. (1985) Inf. Immun. 47, 434-440.

[17] Pugsley, A. and Schwartz, M. (1984) EMBO J. 3, 2393-2397.
[18] Cavard, D., Lloubes, R., Morlon, J., Chartier, M. and Lazdunski, C. (1985) Mol. Gen. Genet. 199, 95-100.

[19] Gray, L., Mackman, N., Nicaud, J.M. and Holland, I.B. (1986) Mol. Gen. Genet. 205, 127-133. 